OLEKSANDRA BIBIK,

Vasyl Stus Donetsk National University (Vinnitsa, Ukraine)

e-mail:o.bibik@edu.donnu.ua, ORCID0000-0002-6610-852X

\title{
CONCEPTS OF ASIA IN JAPANESE PAN-ASIANISM: FROM CULTURAL TO RELIGIOUS AND POLITICAL BORDERS
}

\begin{abstract}
Pan-Asianism in Japan arose as a reaction against the imperialist policy of the West. Throughout the development of Pan-Asianism in Japan, one of the central issues for its followers was the definition of the criteria of "Asianness"; and questioning the boundaries of a new meta-geographical space - Asia. The article is devoted to the issue of the variations of the view on Asia within the Japanese Pan-Asianism of the II half of the XIX-XX centuries. The classification of Asian concepts according to the criterions of "Asianness" is derived. By using the methodology of discourse analysis, the article provides a detailed analysis of the development of these criteria in different contexts of Japanese culture, politics and religion. An analysis of the historical development of the vision of Asia in Japan allowed us to establish the bond between the evolution of views on Asia and the specifics of Pan-Asianism in general. The article also provides an analysis of the sources and history of the term "Asia" in Japan. The central importance of this concept for the phenomenon of pan-Asianism is proved as the result of the study. The study could be seen as the first comprehensive examination of Japanese pan-Asianism in terms of views on a metageographical space which was new to Japan- Asia. The study of this issue in modern Japanese studies is developing in the direction of analysing the historical, economic and political significance of Pan-Asianism, the concepts of Asia and its individual countries in Japan. A detailed examination of the historical formation of the concept of "Asia" in Japan will help to upgrade both the understating of Pan-Asianism and the modern specific of view on the features of "Asian" or "Eastern" civilizations. The presented study offers a broader view of one of the central issues of Japanese pan-Asianism in general.
\end{abstract}

Keywords: Pan-Asianism; the concept of "Asia"; the concept "the West"; the concept "the East"; "Hakko Ichiu"; Western imperialism; "sangoku".

\section{Introduction}

The beginning of discussions around the definition of the term and the concept of "Asia" defines the formation of the Pan-Asianism as movement and ideology. The formation of ideas about "Asia" and "Asianness" is one of the consequences of the Meiji Revolution (1868). The consequences also include a rethinking of traditional geographical, meta-geographic and ideological concepts: the transformation from a Synocentric to Eurocentric model of the world, the emergence of "nation" and Japan's reflection on its place and mission on the new world map. The list of countries that are part of the "Asian" space varied in the Pan-Asian teachings depending on the groups of common features and criteria that are drawn to the representatives of a particular Pan-Asian trend. The article is devoted to examining the varieties of criteria for "Asianness" and understanding the concept of "Asia" at different stages of Japanese pan-Asianism's development in general.

The object of the article is the Japanese pan-Asianism. Subject - the concept of "Asia" as a centre of Japanese pan-Asianism in the second half of XIX-XX centuries. The article aims to determine the variability of understanding the concept of "Asia" in Japanese pan-Asianism of the second half of XIX-XX centuries. By the purpose of the article, the following tasks were identified: to study the historiography of a given topic; to identify the features of understanding Asia in Japan; to classify the varieties of the concept of "Asia" and the criteria of "Asianness" according to the types of pan-Asianism.

The main attention of both Western and Japanese scholars in the area of Pan-Asianism is focused on the historical, political and economic side of the phenomenon. The question of the ideal of Asian unity and solidarity was revealed in the study of K. Szpilman and S. Saaller. Researches of C.V. Hoon, Eri Hotta, P. Katzenzenstein are examining political and economic relations between Asia' countries. Analysis of the view on "Asia" within different conceptions of Pan-Asianism followers (such as Okawa Shumei, Ishiwara Kanji, Tanaka Ippei, Tanaka Chigaku, Okakura Tenshin) is conducted in work of S.V. Kapranov, Nobuo Misawa, H.M. Kramer, G. Iguchi.

The focus of the study for such Japanese researchers as Takeuchi Yoshimi, Yoshikawa Yukie, Hamashita Takeshi is the problem of the concept of "Asia" as a centre of Japanese pan-Asianism. P. Duara deals with the issues of pan-Asianism as a civilizational discourse. Researches of H.M. Kramer, Nobuo Misawa, W. Branderburg is devoted to the study of the religious side of the phenomenon of pan-Asianism. Aspects of Pan-Asian politics and ideology 
are considered in the works of S. Saaller, Hazami Naoki, Saga Takashi, Kozumi Junitsiro, E.V. Zhukov, K.V. Malov, V.E. Molodyakov.

Studies of Pan-Asianism in Ukrainian' Oriental Studies now being in the early stage of development. A significant contribution in this area belongs to S. Kapranov. Besides, mentions of some Pan-Asian figures and concepts are found in the works of O. Borodina, V. Kurilo, P. Kutuev, T. Pron, G. Baka and O. Salikova. However, the current state of studying of this issue could be characterized as the lack of comprehensive research on pan-Asianism in general and the concepts of "Asia" in Japanese panAsianism in particular.

\section{Methodology}

The study was conducted by a mixed methodological approach, which means the combination of methods of philological, historical, philosophical and social sciences. To study the varieties of views on Asia in Japanese PanAsianism were used methods of analysis, systematization, unification and hermeneutic. As for the study of PanAsianism, to work not only with a narrative but also with discourse, the methodology of discourse analysis is required. By this method the using of a wider array of material to explore variations of the concept of "Asia" in ideological, religious and political discourses became possible. The historical method is used to discover the evolution of representations of Asia in Japan. Methods of classification, analysis and synthesis were used to analyses the variability of the apprehension of the criteria of "Asianness".

An interdisciplinary approach was used to comprehensively consider the concept of Asia. The research was conducted by following the principle of avoiding Eurocentrism in Oriental studies. This approach allows us to move away from the replacement of original terms of oriental thought with the concepts of Western history and political science and contributes to the formation of an objective view on the phenomenon that understudy.

\section{Results}

The article could be seen as the first comprehensive study of the concept of "Asia" in the history of Japanese pan-Asianism. Based on the work of researchers in the field of history of Japanese identity and political relations of Japan with other Asian countries, the author analyses the formation of the concept of "Asia" in Japan during the second half of XIX - XXI centuries. Thus, in the results of the study:

- the sources of origin of the term "Asia" in Japan were analysed;

- determined the history of the evolution of the concepts of "Asia" in Pan-Asianism;

- variability of understanding of "Asia" in pan-Asianism is classified according to the criteria of "Asianness";

- the development of the concepts of "Asia" is compared to the development of Japanese pan-Asianism in general;

- the central importance of the concept of "Asia" for a comprehensive understanding of Pan-Asianism in Japan is proved.

\section{Discussion}

The concept of "Asia" (亜細亜 - "ajia", or 亜 - "a") was brought to Japan by Jesuit missionaries in the XVI century.
This word first appears in the Chinese map of the world from 1600 , which was carried out under the supervision of the leadership of the Jesuit mission in China Matteo Ricci (1552-1610) (Kytay ochyma Aziyi, 2017: 151). The concept of "Asia" originated in Ancient Greece for the perception of "eastern countries" as opposed to "western countries". From the VI century, the division of the world into Europe, Asia and Africa were widely known in the ancient world thanks to geographical works of Anaximander and Hecate. In Asia itself, this concept was originally used as an empty geographical term and did not have any specific meaning; by "Asia" was understand too large and varied region (Saaler, 2007).

The term "Asia" became more widely used in Japan since the middle of the 19th century, i.e. after the Meiji Revolution, in response to the growing the diplomatic, militaristic and economic influence of the West. As S. Saaller and K. Szpilman noted, the term "Asia" at this time "ceased to be just a technical term used by East Asian cartographers in response to the threat of Western colonialism" and became the foundation for the formation of a new Japanese identity (Szpilman, Saaler, 2011: 2). During this period, the concept of "Asia" came into the focus of Japanese pan-Asianism and began to be used as a foundation for the unification of peoples who began to define themselves as Asian.

During the Meiji period (1868-1912) and early Taisho period (1912-1926), the basis for the formation of the Asian identity in Japan was countries of Northeast and East Asia. The core for Pan-Asian identity in this time was Japan, China, Korea and Vietnam, i.e. the region of distribution of Chinese characters. The concept that writing is the foundation of identity formation is called "do: sho" (同文 "unified writing") (Saaler and Koschmann, 2008). In some Pan-Asian teachings, "Asia" also included Mongolia, Manchuria, Eastern Siberia, the far east of Russia, India, and Islamic countries based on religious (同教 - "do: kyo") and racial (同種 - "do: shu") unity or geographical proximity. In the further development of the political and ideological side of Pan-Asianism, starting from the Showa period (1926-1989), the concept of "Asia" provided wider boundaries for the development of economic and political ties between the named countries (Szpilman and Saaler, 2011: 14-16).

The emphasis on the region of India, Japan and China at the beginning of the development of ideas about Asia in Japan finds its historical roots in the concept of "three countries" (三国 - "sangoku") (Bialock, 2007: 186). Already in the Heian period (794 - 1185) in such texts as "Collection of stories about the past" (「今昔物語集」- "Konjyaku Monogatari Shu") and "Chronicle of the three countries" (「三国伝記」 - "Sangoku Denki") material was organized according to the geographical division into India, China and Japan. The use of this term in the works of some PanAsian thinkers, such as Okakura Tenshin and his followers, indicates the influence of traditional geographical representations on the concepts formed after the metageographical revolution of Meiji ${ }^{1}$ (Peattie, 2008).

\footnotetext{
1 The assessment of the Meiji Revolution as meta-geographical is given in the works of such scholars as S. Kapranov following the development of meta-geography as discipline in the works
} of V. Gokhman, B. Gurevich. 
From the end of the Edo period (1603-1868) and at the beginning of the Meiji period, there were several opposing views of the Asian region in Japan. The first of them focused on the backwardness of Asia from Europe's point of view (and in this connection on the necessity to either "To raise Asia" (興亜 - "ko: a") or "To go away from Asia" (脱亜, "datsu a") and focusing on Europe and own development (入欧 - "nu:o"). The second view is pointing out the uniqueness of Asian spirituality and culture and on the necessity to develop this culture in oppose with the West. The idea of the necessity to support Asia was transformed into pan-Asianism in early as the Meiji period through the activities of the first Pan-Asian organizations, such as the Society for the Support of Asia, the Society for the Promotion of Asia, and the Society for Asia. Concepts of Asian identity and the search for answers to the question of the existence of common features between Asian countries have developed in the context of both directions (Duara, 2001).

Considering the origin and development of panAsianism as a type of ideology based on collective regional identity, P. Katzenzenstein, S. Saaller, E. Hotta and other researchers agree that "Asia" in this case is not geographical, but rather a "political construct that is discussed and evolves" (Katzenstain, 1996). Therefore, the formation of this construct takes place in the Pan-Asian discourse of both the reflection around the definition of "Asia" and the possibility of creation and forms of existence of Asian identity.

The work of the Japanese art critic Okakura Tenshin (Okakura Kakuzo - 岡倉 覚三, 1863-1913), who saw the possibility of uniting Asia by defining the unity of tradition philosophical, religious, artistic and spiritual - had a significant influence on the formation of this discourse. Describing the unity of Asian civilizations, he writes as follows: "It is also true that the Asiatic races form a single mighty web. [...] Arab chivalry, Persian poetry, Chinese ethics, and Indian thought, all speak of a single ancient Asiatic peace, in which there grew up a common life, bearing in different regions different characteristic blossoms, but nowhere capable of a hard and fast dividing line. Islam itself may be described as Confucianism on horse-back, sword in hand. For it is quite possible to distinguish, in the hoary communism of the Yellow Valley, traces of a purely pastoral element, such as we see abstracted and self-realized in the Mussulmân races" (Krämer, 2014: 36-37). According to this view, the "Asian" space included everything that non-Western: "Asia is one. The Himalayas divide, only to accentuate, two mighty civilizations, the Chinese with its communism of Confucius, and the Indian with its individualism of the Vedas. But not even the snowy barriers can interrupt for one moment that broad expanse of love for the Ultimate and Universal, which is the common thought-inheritance of every Asiatic race, enabling them to produce all the great religions of the world, and distinguishing them from those maritime peoples of the Mediterranean and the Baltic, who love to dwell on the Particular, and to search out the means, not the end, of life" (Brij, 2007: 1).

At this initial stage of development of the Pan-Asian thought, the terms "race" (人種 - "jinshu") and "nation" (民族 - "minzoku") are formed together with the formation of the concept of Asia (Hoon, 2004: 15). In particular, the greater popularity of the term "race" tell us about the main tendency of pan-Asianism of this period - to overcome the border between Asian countries and create unity. The word "nation" became more common after World War II.

The idea of uniting Asia through the development of Asian traditions will be continued in the further development of the branch of pan-Asianism that Eri Hotta calls "teasist" or "chaism" and in the political movements of the second half of the twentieth century. Apolitical and attempts to find the boundaries of the not yet quite clear space "Asia" are described by the researcher as the general features of this branch of pan-Asianism. Considering the views of Rabindranath Tagore (1861-1941) and Mahatma Gandhi (1860-1948), Hotta emphasizes the existence of common features in their views with the teachings of Okakura Tenshin and Okawa Shumai, and thus the output of this Pan-Asian idea beyond the borders of Japan (Eri Hotta, 2007: 34-68).

One of the key concepts of Pan-Asianism is the idea of searching for the Asian identity and geographical borders of Asia through the assertion of the religious unity or similarity of several religions. The centre for such concepts was, first of all, Buddhism and Islam, which in some philosophical systems were joined by Shinto, Confucianism and Taoism. Depending on the chosen religion, different arguments were given as to the reasons for the unity of cultures, which were called Asian and thus proposed various forms of union between them.

So one of the Japanese Islamic scholars, politician and follower of Pan-Asianism Tanaka Ippei (田中逸平 1884-1934) argues that the formation of a united Asia is possible through the creation of religious syncretism. Looking for opportunities for the formation of syncretism of different religious traditions, he writes: "When I thought about the view of the universe, which was the core idea of the old Chinese belief system, I could not help but see how the divinity of Muhammad resembled that of Kami (God) in Japan. I found a relationship between Confucianism and Islam as well as a relationship between Confucianism and Zen Buddhism; as a result, I discovered the connection between Islam and Shintoism" (Collection of works by Ippei Tanaka, 2002: 109). In 1931, Tanaka formed the society "Go-Ichi Kai" (「五一会」 - "Society of Unity", literally "Society of Unity of the Five"), which aims was to determine the formation of a fundamental identity based on the synthesis of the five world religions: Taoism, Islam, Buddhism, Christianity, Confucianism and Shinto. In creating such a synthesis, Tanaka saw an opportunity to find not only religious truth but also a political weapon that could help in the fight against the West (Collection of works by Ippei Tanaka, 2002: 283).

Based on the concept of "jihad", Tanaka draws an analogy between the struggle of the Turks against the West and the current situation in Japan. Based on an analysis of the historical experience of Muslims, the scholar believes that Islam can support the "Japanese spirit" and promote the unification of Asian countries under the leadership of Japan. In his "Islam and Pan-Asianism" essay (1924) he notes: "Some time ago, in "The Future of Chinese Muslims and the Japanese Spirit" essay, I showed that the Japanese spirit and the Muslim spirit have much in common, and this fact will be a great advantage for future Japanese politics". In that way, Tanaka stress that the formation of 
religious synthesis and the adoption of Islam will contribute to the future success of Japan. On this basis, Tanaka Ippei proposes to include the countries of the Muslim region to the Asian countries (Collection of works by Ippei Tanaka, 2002: 252).

Prominent Pan-Asianists followers, such as Okawa Shumei (大川周明, 1886-1957) and Toshiko Izutsu (井筒俊彦 - 1914-1993) also drew attention to the importance of Islam for the unification of Asia. Okawa Shumei sees Islam as "potential that can be used in the fight against the West" because, in his view, it is Islam that overcomes the contradictions between politics and religion (Brandenburg, 2018). Okawa considers the emergence of such contradictions to be one of the main reasons for the coIonization of India. Therefore, proving the similarity between Confucianism and Islam he proposes to include the regions of the Muslim East in Asia (Shimamoto Takamitsu, 2008). In the concept of "Eastern philosophy" Toshihiko Izutsu also emphasizes the common features of these traditions.

The Buddhist direction of development of Pan-Asian concepts of Asia is most vividly developed in the views of followers of Nichiren Buddhism school (日蓮宗 - "NichirenShu"), such as Nichizatsu Fujii (藤井日達, 1885-1985), Tanaka Chigaku. (田中智學, 1861-1939), Ishiwara Kanji (石原莞爾, 1889-1949) and other representatives of this trend (Iguchi, 2006). The specificity of this Pan-Asian current is the idea of uniting not only Asia but the whole world under the slogan of Nichiren school.

It is Tanaka Chigaku who was the author of the famous credo "Hakko Ichiu" (八紘一宇, "eight corners under one roof"). The slogan "Hakko Ichiu" comes from the phrase of Emperor Jimmu (神武天皇, "Jimmu Tenno:", 771-585), recorded in the historical monument "Annals of Japan" (「日本書紀」- "Nihon Shoki"): "I shall cover the eight directions and make them my abode" (「八紘を掩うて宇と

為さん」- "hakko: o o: ute ie to nasan") (Iguchi, 2006: 69). Tanaka interprets this expression in the context of the sacred justification of the claim that the whole world should be united by the Buddhist school of Nichiren and opposes the use of this term in a militaristic sense. But eventually, the slogan "Hakko Ichiu" will become one of the ideological foundations for the policy of unification of Asia under the leadership of Japan.

From the period of the Showa, the term "Hakko Ichiu" began to be used in the imperialism and expansionism's contexts. In the document "Basic Principles of regulation of national policy" (「基本国策要綱」- "Kihon kokusaku yo: ho:") from 1940, this expression is interpreted as follows: "The basic aim of Japan's national policy lies in the firm establishment of world peace in accordance with the lofty spirit of Hakko Ichiu, In which the country was Founded, and in the construction, as the first step, of a new order in Greater East Asia, having it's for the Solidarity Foundation of Japan and Manchoukou Chin". In a similar sense, the term "Hakko Ichiu" was used in the rhetoric of the Society for the Study of Showa (「昭和研究会」"Sio:wa Kenkyu: Kai") and the East Asian Community (「東覀連盟」- "To: Renmey"). Most often during this period in the "Hakko Ichiu" included the regions of Manchuria, China and countries that were neighbours to Japan. According to F. Jonkir, the expansion of the borders of imaginary Asia to the eastern part of the Pacific Ocean took place only after 1941 year.

The synthesis of Confucian and Buddhist ideas is seen in Ishiwara Kanji' concepts of Asia and the East. The East Asian Federation created by him is considered to be one of the key figures of the militaristic part of Japanese PanAsianism. Among the main goals of the organization were, on the one hand, allegations of the necessity to maintain military support for Japan, on the other hand - attempts to stop the war in China. As one member of the East Asian League, Ichiji Norihiko (伊地知則彦) wrote: "The path Nichiren's Rissho Ankoku-ron is the path to harmony between people, to the East Asian Federation" (Collection of works by Ishiwara Kanji, 1976-77: 85). Ishiwara Kanji's vision of Asia included the idea of Korean self-government and the independence of Manchuria (which, according to Ishiwara Kanji's project was to become a model of peaceful coexistence of Japanese, Chinese, Manchurian and Mongolian nations).

Ishiwara Kanji singles out the so-called "king way" (王道 -"o: do:") as specifics of Asian and Eastern cultures. The opposite of the "king way" was the "despotic way" (覇道 - "hado:"), which characterizes the West. By "cultures of the king way" are meant Asian civilizations, for which the moral standard of nonviolence relations between countries and the norm for the powerful people is not to abuse of their power, but to protect of the weak. Ishiwara uses the term "hado:" to refer not only to Western imperialism but also to the West's inability to take history further than the stalemate of World War I. In this sense, Ishiwara's teaching concludes that Japan's victory in the war with the United States and the Soviet Union will also be the victory of the "king way" over the "despotic path" (Collection of works by Ishiwara Kanji, 1976-77). The terms "o:do:" and "hado:" have been commonly used in the context of Japanese Pan-Asianism since its inception. The idea of the peacefulness of Asian civilization arose in the pan-Asianism of the Meiji era (in the teachings of Okakura Tenshin, Okawa Shumei, Toshihiko Izutsu, etc.) and gradually became one of the leading characteristics of the specifics of Asia and Asian cultures.

Unlike Buddhism, Confucianism does not play a leading role in the history of Pan-Asian views of Asia. Confucianism had the most significant influence on the formation of ideas about Asia in the 1990s in the form of a "theory of Asian values." At this time, the term "Asian values" became popular as a means to achieve social good through the creation of a common Asian identity. According to researchers of this theory, W. Schwentkler and C. Hoon, the discourse on Asian values were formed both under the influence of the legacy of Pan-Asian thought and in the context of Western borrowings as antitheses to Western political and ethical concepts (Hoon, 2004).

The theory of Asian values states the relativism of the concept of human rights, the predominance of the collective consciousness over the individual and the understanding of the nation as a family, the evaluation of social and economic rights as more important than political and the government's right to judge over human rights. In addition to those core values, labour work, discipline, thrift, and respect for authority are also mentioned in this context (Hoon, 2004: 2-4). The theory was supported by political leaders of Asian countries, such as Japan, Malaysia, South Korea, Singapore, China. 
The theory of Asian values states the relativism of the concept of human rights, the predominance of the collective consciousness over the individual and the understanding of the nation as a family, the evaluation of social and economic rights as more important than political and the government's right to judge over human rights. In addition to those core values, labour work, discipline, thrift, and respect for authority are also mentioned in this context (Hoon, 2004: 2-4). The theory was supported by political leaders of Asian countries, such as Japan, Malaysia, South Korea, Singapore, China.

After World War II, Pan-Asian reflection on Asian identity took the form of political and economic organizations. Among such organizations could be mentioned the ASEAN Free Trade Area (AFTA) and the Association of East Asian Nations (ASEAN), the central ideas of which are the thesis of the necessity to establish good relations between Asian countries based on equal partnership. For example, ASEAN has set itself the following goal: "We, the people of East Asia, aspire to create an East Asian community of peace, prosperity and progress based on the full development of all peoples in the region. Concurrent with this vision is the goal that the future East Asian community will make a positive contribution to the rest of the world" (Towards an East Asian Community, 2001). At this time, the leitmotif of the Pan-Asian' discourse was no longer the search for Asian identity and definitions of "Asia" as a metageographical space but the search for new forms of relations between Asian countries for common development.

\section{Conclusions}

Thus, a prominent feature of Japanese pan-Asianism throughout all its development was the discourse of looking for the answer to the question of the definition of "Asia" and Asianness. Gradually, the term "Asia" became commonplace in the region, where the Asian identity was formed as a result of the activities and development of Pan-Asian thought. Elements of the region's traditional geographical terms, such as the "sangoku" and "Hakko Ichiu", have been transformed into a new form in response to the challenges of the times.

As a result of reflection on the borders of Asia and the presence of common features between different Asian cultures, several common directions were formed. In addition to highlighting the common writing system (the region of distribution of Chinese characters), one race (the concept of "yellow race"), the emphasis was on the common religions, cultural characteristics and values. Since the concept of Asia arose in the process of confrontation between Eastern and Western countries, PanAsianism often appealed to such features of Asian cultures as peace, spirituality, respect for the weak, and collective consciousness. The gradual development of this idea of Asia determined the actual formation of Asian identity in the region and preceded the development of the ideological side of Pan-Asianism.

From the second half of the $X X$ century, the Pan-Asian discourse on the definition of Asia takes the form of the creation of political and economic organizations between the countries participating in the Pan-Asian dialogue. The analyzed aspects of the Pan-Asian discourse, as well as the named features of Asian and Eastern cultures are gradually entering not only the self-consciousness of Asian cultures but are becoming common characteristics of the civilizations that we call Eastern.

\section{REFERENCES}

Bialock, David T. (2007). Eccentric Spaces, Hidden Histories: Narrative, Ritual, and Royal Authority from The Chronicles of Japan to The Tale of the Heike. Stanford University Press, $488 \mathrm{p}$.

Brandenburg, U. (2018). The Multiple Publics of a Transnational Activist: Abdurresid Ibrahim, Pan-Asianism, and the Creation of Islam in Japan. Welt Des Islams, 58(2), 143-172. DOI: https://doi.org/10.1163/15700607-00582p01

Hoon, C. Y. (2004). Revising the "Asian Values" Argument Used by Asian Political Leaders and Its Validity. Research Collection School of Social Sciences. Singapore Management University, p. $154-174$.

Szpilman, Ch. W. A. \& Saaler, S. (2011). Pan-Asianism as an Ideal of Asian Identity and Solidarity, 1850-Present. The Asia-Pacific Journal. Retrieved from https://apjjf.org/-Sven-Saaler-Christopher-W--A--Szpilman/3519/article.pdf

Duara, P. (2001). The discourse of civilization and Pan-Asianism. Journal of World History, 12(1), 99-130. DOI: https://doi.org/ 10.1353/jwh.2001.0009

Eri, Hotta (2007). Pan-Asianism and Japan's Was 1931-1945. New York: Palgrave Macmillan, $290 \mathrm{p}$.

Iguchi, G. S. (2006). Nicherenism as Modernism: Imperialism, Fascism, and Buddhism in Modern Japan. San Diego: University of California, $328 \mathrm{p}$.

Katzenstain, Peter J. (1996). Introduction: Asian Regionalism in Comparative Perspective. In: Network Power. Japan and Asia. Ithaca; London: Corell University Press, pp. 1-44.

Brij, Tankha (2007). Okakura Tenshin and Pan-Asianism: Shadows of the Past. New Delhi: Sampark, $189 \mathrm{p}$.

Peattie, M. R. (2008). Pan-Asianism in modern Japanese history: Colonialism, regionalism and borders. Pacific Affairs, 81(2), 285-287.

Saaler, S. (2007). The construction of regionalism in modern Japan: Kodera Kenkichi and his "Treatise on Greater Asianism" (1916). Modern Asian Studies, 41, 1261-1294. DOI: https://doi.org/ $10.1017 / \mathrm{s} 0026749 \times 06002605$

Saaler, S., Koschmann, J. V. (2008). Pan-Asianism in Modern Japanese History: Colonialism, Regionalism, and Borders (vol. 11, pg 288, 2006). Social Science Japan Journal, 11(2), 369-369. DOI: https://doi.org/10.1093/ssjj/jyn028

Krämer, Hans Martin (2014). Pan-Asianism's Religious Undercurrents: The Reception of Islam and Translation of the Qur'ān in Twentieth Century Japan. The Journal of Asian Studies. P. 619-640. Retrieved from http://journals.cambridge.org/abstract_S0021911814000989

Towards an East Asian Community: Region of Peace, Prosperity and Progress (2001). East Asian Vision Group Report. Retrieved from http://www.asean.org/archive/pdf/ east asia vision.pdf

Collection of works of Ippei Tanaka.

Kytay ochyma Aziyi (2017). Instytut skhodoznavstva im. A. YU. Krymskoho NAN Ukrayiny, Ukrayinska asotsiatsiya kytayeznavtsiv. Kyiv, 316 s. (In Ukrainian)

Shimamoto, Takamitsu, 嶋本, 隆光 (2008). Okawa Shumei' Religious Studies. The road to Islamic studies. 大川周明の宗教研究ーイスラーム研究への道一. University of Osaka大阪大学, $22 \mathrm{p}$.

Collection of works of Ishiwara Kanji. 石原莞爾全集。全 8 巻、 東京: 石原莞爾全集刊行会、1976-1977 年 
Олександра Бібік,

Донецький національний університет імені Василя Стуса (м. Вінниия, Україна)

e-mail: o.bibik@edu.donnu.ua, ORCID 0000-0002-6610-852X

\section{КОНЦЕПТИ АЗІї В ЯПОНСЬКОМУ ПАНАЗІАТИЗМІ: ВІД КУЛЬТУРНИХ ДО РЕЛІГІЙНИХ ТА ПОЛІТИЧНИХ МЕЖ}

Паназіатизм у Японії виник як реакція проти західної політики імперіалізму щодо колонізації Азії. Залежно від виділення релігійних, політичних, расових, культурних, географічних чи економічних доводів для об'єднання країн формувалися окремі паназійські напрямки з варіативним відношенням до Азії. Стаття присвячена розгляду варіацій погляду на Азію в японському паназіатизмі ІІ половини XIX - XX ст. У результаті роботи виведено класифікацію концептів Азії відповідно до критеріїв "азійськості". За допомогою методології дискурс-аналізу в статті проводиться детальний аналіз розвитку цих критеріїв в різних контекстах японської культури, політики та релігії. Аналіз історичного розвитку бачення Азії в Японії дозволив встановити взаємозв'язок між еволюцією поглядів на Азію та специфікою паназіатизму в цілому. Також у статті проводиться всебічний аналіз джерел та історії терміну "Азія" в Японії та доводиться центральне значення цього концепту для феномену паназіатизму. Міждисциплінарній підхід та відхід від європоцентризму дозволив отримати комплексний погляд не тільки на концепти "Азії" але й на феномен японського паназіатизму загалом. Дослідження являє собою перший комплексний розгляд японського паназіатизму з точки зору поглядів на новий для Японії мета-географічний простір - Азію. Розробка даної проблематики в сучасній японістиці розвивається в напрямку аналізу історичного, економічного та політичного значення паназіатизму, концептів Азії та окремих їі країн в Японії. Детальний розгляд історії становлення поняття про "Азію" в Японії допоможе глибше зрозуміти не тільки паназіатизм, але й сучасну специфіку розуміння особливостей "азійських" або "східних" цивілізацій. Представлене дослідження пропонує більш широкий погляд на одне 3 центральних питань японського паназіатизму в цілому.

Ключові слова: паназіатизм; концепт "Азія"; концепт "Захід"; концепт "Схід"; "хакко іціу"; західний імперіалізм; "сангоку".

(C) Oleksandra Bibik

Надійшла до редакції: 11.05.2020

Прийнята до друку: 03.06.2020 